\title{
Competition Policy in the European Union
}

\author{
Michelle Cini \\ and \\ Lee McGowan
}


C Michelle Cini and Lee McGowan 1998

All rights reserved. No reproduction, copy or transmission of this publication may be made without written permission.

No paragraph of this publication may be reproduced, copied or transmitted save with written permission or in accordance with the provisions of the Copyright, Designs and Patents Act 1988, or under the terms of any licence permitting limited copying issued by the Copyright Licensing Agency, 90 Tottenham Court Road, London W1P 9HE.

Any person who does any unauthorised act in relation to this publication may be liable to criminal prosecution and civil claims for damages.

The authors have asserted their rights to be identified as the authors of this work in accordance with the Copyright, Designs and Patents Act 1988.

First published 1998 by

MACMILLAN PRESS LTD

Houndmills, Basingstoke, Hampshire RG21 6XS

and London

Companies and representatives

throughout the world

ISBN 978-0-333-64302-0 ISBN 978-1-349-26710-1 (eBook)

DOI 10.1007/978-1-349-26710-1

A catalogue record for this book is available from the British Library.

$\begin{array}{rrrrrrrrrr}10 & 9 & 8 & 7 & 6 & 5 & 4 & 3 & 2 & 1 \\ 07 & 06 & 05 & 04 & 03 & 02 & 01 & 00 & 99 & 98\end{array}$

Copy-edited and typeset by Povey-Edmondson

Tavistock and Rochdale, England

Published in the United States of America 1998 by

ST. MARTIN'S PRESS, INC.,

Scholarly and Reference Division,

175 Fifth Avenue, New York, N.Y. 10010

ISBN 978-0-312-21505-7 


\section{Contents}

List of Boxes and Tables viii

Preface $\quad$ ix

List of Abbreviations $\quad$ xi

1 Introduction 1

Competition and competition policy $\quad 2$

Origins and influences $\quad 5$

Competition policy and European integration 10

$\begin{array}{ll}\text { Organisation of the book } & 13\end{array}$

2 A History of European Competition Policy 15

From coal and steel to EEG 17

The first fifteen years: 1958 to 1972

From recession to stagnation: 1973 to 1981

Towards a 'new' competition policy $\quad 29$

Conclusion $\quad 36$

3 The Institutions of European Competition Policy 38

The Parliament and the Council $\quad 39$

The European Commission $\quad 41$

The European Courts $\quad 53$

Conclusion $\quad 58$

4 Restrictive Practices Policy 60

Article 85[81]: regulating restrictive practices 61

Block exemptions $\quad 66$

$\begin{array}{ll}\text { Policy practice } & 69\end{array}$

Assessing restrictive practices policy $\quad 75$

$\begin{array}{ll}\text { Conclusion } & 79\end{array}$

5 Monopoly Policy $\quad \mathbf{8 0}$

Article 86[82] in context 80 
The Commission's analysis: demonstrating 'dominance' 83

The Commission's analysis: assessing 'abuse' $\quad 88$

Assessing monopoly policy $\quad 94$

$\begin{array}{ll}\text { Conclusion } & 96\end{array}$

6 Commission Decision-Making in Restrictive Practices and Monopoly Cases 97

Exposing anti-competitive practices 97

Fact-finding and the investigation 102

The formal proceedings 106

$\begin{array}{ll}\text { The decision-taking stage } & 109\end{array}$

Negotiating informal outcomes 111

$\begin{array}{ll}\text { Conclusion } & 115\end{array}$

7 Merger Policy 116

The origins of European merger control 116

Towards a coherent merger regime: procedure and practice

Assessing merger policy $\quad 126$

Reforming the European merger rules 131

Conclusion 133

8 State Aid Policy 135

Organisation, powers and decision-making $\quad 136$

Towards a cohesive state aid regime 143

Policy content 146

Assessing state aid control 154

$\begin{array}{ll}\text { Conclusion } & 158\end{array}$

9 The 'New' Competition Policy: The Public Sector and the Utilities $\quad 160$

Origins and influence $\quad 161$

Policy instruments 164

The Commission in action $\quad 166$

$\begin{array}{ll}\text { Conclusion } & 178\end{array}$

10 Decentralising European Competition Policy 179

Decentralisation and the national courts 181

$\begin{array}{ll}\text { The national competition authorities } & 186\end{array}$ 
Decentralisation and the national competition authorities

Conclusion

11 The Internationalisation of European

The limits to internationalisation

Towards an international regime: the role of international organisations

Unilateralism and bilateralism

Towards a pan-European regime

Conclusion

\section{Conclusions}




\section{List of Boxes and Tables}

\section{Boxes}

3.1 The Competition Commissioners

3.2 The Commission's directorates-general, services and other relevant bodies

3.3 The structure of DGIV

4.1 Article 85[81] of the EEC Treaty

4.2 Block exemption regulations in operation (1997) 68

5.1 Article 86[82] of the EEC Treaty 82

7.1 The procedure in EU merger control 124

8.1 Article 92[88] of the EEC Treaty 138

9.1 Article 90[86] of the EEC Treaty 165

10.1 National authorities' capacity to apply Articles 85[81] and $86[82]$ of the EEC Treaty

\section{Tables}

6.1 New anti-trust cases, $1996 \quad 101$

6.2 Formal decisions taken, $1996 \quad 109$

6.3 Informal settlements, $1995 \quad 113$

$\begin{array}{lll}7.1 & \text { Merger decisions 1990-96 } & 125\end{array}$

8.1 New state aid cases, 1993-96 141

8.2 State aid decisions, 1992-96 144

8.3 State aid decisions by member state, $1996 \quad 144$

8.4 State aid to industry, 1990-94 147 


\section{Preface}

This book has been written for the uninitiated who have had little occasion to delve into the workings of Directorate-General IV of the European Commission, the body in charge of European competition policy. We know from our own experience that very many students approach the European Union's restrictive practices policy, the regulation of European mergers and acquisitions, and the control of European monopolies, with trepidation. This is not at all surprising. The literature on competition policy is immense, and frequently assumes a legal or economic background. It often seems too arcane or technical for non-specialists, and many are understandably put off as a result.

Contrast this perception of the European competition regime with the coverage the policy gets in the specialist European and financial press. Here, European competition policy is often identified as one of the most 'sexy' of the European policies. Indeed, the role of the European Commission, which involves so-called 'dawn raids' on the offices of allegedly miscreant firms and the imposition of massive fines on multinational companies, which has serious implications for national and regional industrial and economic policies, and which places the policy firmly at the heart of the single market project, serves to make the European competition regime a potentially controversial and highly political and politicised policy field.

Herein lies the justification for our book. Given the gap that exists between these two very different perceptions of European competition policy, we realised that there was also a gap in the literature. As authors of this book, we are convinced that European competition policy is no more complex or 'technical' than any other European policies. Our mission, then, was to write an introductory study of the policy that would be accessible to students of all disciplinary backgrounds, and anyone else with an intellectual or professional interest in the subject, without losing any sense of its complexity. It aims to invite a new audience to explore what is truly a fascinating aspect of the EU's work. 
Two stylistic points are worthy of note at this point. First, assuming it is ratified, The Treaty of Amsterdam will result in the renumbering of many of the treaty provisions referred to in this book. Where this is the case the pre-Amsterdam numbering is used in the text, with the new post-Amsterdam changes given in square brackets immediately following. Second, the series style is to use European Union (EU) throughout except when referring to a specific constituent organisation or exclusively to a period before the creation of the EU in November 1993.

The book itself is based on our own separate original research, and has thus built upon our different interests and expertise. During the time we have spent working on competition issues we have inevitably built up a huge debt of thanks to numerous people who have informed, inspired and supported us in this project. While a comprehensive list would require a book in itself, we would particularly like to thank Stephen Wilks, without whom neither of us would be working on competition policy; Steven Kennedy and Neill Nugent for their constructive criticism and gentle encouragement; all those who gave their time to offer advice on individual chapters; and, most importantly our families, especially Lynn and Oliver, and our friends and colleagues, for their patience and moral support, particularly during the latter stages. It only remains to be said that all errors within the book remain, as ever and forever, on the consciences of the authors alone.

Michelle Gini

LeE McGowan 


\section{List of Abbreviations}

$\begin{array}{ll}\text { ABA } & \text { American Bar Association } \\ \text { BEUC } & \text { European Bureau of Consumers' Unions } \\ \text { BKartA } & \text { Bundeskartellamt (German Federal Cartel Office) } \\ \text { GEECs } & \text { Central and East European Countries } \\ \text { GET } & \text { Common External Tariff } \\ \text { GFI } & \text { Court of First Instance } \\ \text { GLP } & \text { Competition Law and Policy Committee (of the } \\ & \text { GATT) } \\ \text { GMLR } & \text { Common Market Law Reports } \\ \text { DG } & \text { Directorate-General } \\ \text { DGI } & \text { Directorate-General I (formerly covering all external } \\ & \text { relations matters) } \\ \text { DGII } & \text { Directorate-General II (Economic and Financial } \\ & \text { Affairs) } \\ \text { DGIII } & \text { Directorate-General III (Industry) } \\ \text { DGIV } & \text { Directorate-General IV (Competition) } \\ \text { DGVII } & \text { Directorate-General VII (Transport) } \\ \text { DGXIII } & \text { Directorate-General XIII (Telecommunications) } \\ \text { DGXVI } & \text { Directorate-General XVI (Regional Policies and } \\ & \text { Cohesion) } \\ \text { DGXVII } & \text { Directorate-General XVII (Energy) } \\ \text { DTI } & \text { Department of Trade and Industry (UK) } \\ \text { EC } & \text { European Community } \\ \text { EGJ } & \text { European Court of Justice } \\ \text { EGO } & \text { European Cartel Office } \\ \text { EGR } & \text { European Court Reports } \\ \text { ECSG } & \text { European Coal and Steel Community } \\ \text { ECU } & \text { European Currency Unit } \\ \text { EEA } & \text { European Economic Area } \\ \text { EEC } & \text { European Economic Community } \\ \text { EFTA } & \text { European Free Trade Association } \\ \text { EP } & \text { European Parliament } \\ \text { EU } & \text { European Union } \\ \text { EURATOM } & \text { European Atomic Energy Community } \\ & \end{array}$


FTC Federal Trade Commission (US)

GATT General Agreement on Tariffs and Trade

GNP Gross National Product

G7

Group of Seven (industrialised countries)

IEM Internal Energy Market

IT

ITO

KPN

Information Technology

LS

International Trade Organisation

MCR

Dutch Post Office

MEP

Legal Service (of the Commission)

MMC

Merger Control Regulation

MTF

Member of the European Parliament

NAFTA

Monopolies and Mergers Commission

NGA

NTB

Merger Task Force

OEGD

North American Free Trade Association

National Competition Authority

Non-Tariff Barrier

$\begin{array}{ll} & \text { Development } \\ \text { OFGAS } & \text { Office of Gas Supply } \\ \text { OFT } & \text { Office of Fair Trading } \\ \text { OFTEL } & \text { Office of Telecommunications } \\ \text { OFWAT } & \text { Office of Water Supply } \\ \text { OJ } & \text { Official Journal }\end{array}$

PHARE Poland-Hungary Aid for Economic Reconstruction

PTO

Post and Telecommunications Office

R\&D

Research and Development

SEA

Single European Act

SEM

Single European Market

SG

Secretariat-General

SME

TENs

Small and Medium-Sized Enterprise

TEU

UK

Trans-European Networks

Treaty on European Union (Maastricht Treaty)

UNCTAD United Nations Conference on Trade and

Development

UNICE European Employers' Association

US

United States (of America)

WTO World Trade Organisation 